\title{
Neonatal mortality: morbidity pattern and risk factors in a resource- limited centre in North Central Nigeria
}

*Efe Abolodje ${ }^{1}$

Sri Lanka Journal of Child Health, 2021; 50(3): 408-415

\begin{abstract}
Introduction: Neonatal mortality rates in most developing countries, including Nigeria, are unacceptably high, and are a reflection of underdevelopment. Neonatal mortality rates vary with prevailing disease conditions and socioeconomic characteristics, such as wealth, maternal education, geographic zone of residence, and place of residence.
\end{abstract}

Objectives: To determine the morbidity pattern and risk factors associated with neonatal mortality in the neonatal unit of Dalhatu Araf Specialist Hospital, Lafia, North Central Nigeria

Method: The study was a review of all cases admitted to the neonatal unit from $1^{\text {st }}$ January to $31^{\text {st }}$ December 2018. Socio-demographic data and clinical parameters of cases were entered into a Microsoft Excel sheet and analysis of data was by SPSS version 23.

Results: Four hundred and twenty-eight cases were reviewed of which $217(50.7 \%)$ were males, 348 $(81.3 \%)$ were term infants and $373(87.1 \%)$ were delivered in health facilities. Forty-five (10.5\%) neonates died during the period under review, and all deaths were due to asphyxia, respiratory distress syndrome (RDS) and neonatal sepsis. Low socioeconomic class, low birth weight and preterm delivery were significantly associated with mortality $(\mathrm{p}<0.05)$. Risk of dying was highest with preterm neonates with $\mathrm{RDS}(\mathrm{AOR}=3.7$; CI 95\%= $1.0-13.1 ; p=0.04$ )

${ }_{1}^{1}$ Lecturer, Department of Paediatrics, Delta State University, Abraka, Nigeria and Honorary Consultant Paediatrician, Delta State University Teaching Hospital, Oghara, Nigeria

*Correspondence: efexabo@gmail.com

iD https://orcid.org/0000-0003-2986-7401

(Received on 19 July 2020: Accepted after revision on 24 August 2020)

The authors declare that there are no conflicts of interest

Personal funding was used for the project.

Open Access Article published under the Creative

Commons Attribution CC-BY (c) (i) License
Conclusions: The three leading causes of neonatal morbidity and mortality at the study centre were RDS, perinatal asphyxia and neonatal sepsis. However, prematurity was the most important predictor of mortality.

DOI: http://doi.org/10.4038/sljch.v50i3.9688

(Keywords: Neonate, mortality, morbidity, risk factors)

\section{Background}

Neonatal mortality rates (NMRs) in most developing countries, including Nigeria, are unacceptably high, and are a reflection of underdevelopment and poverty ${ }^{1,2}$. In 2018, 2.5 million deaths were recorded among children in the first 4 weeks of life, about $10 \%$ of which were from Nigeria alone ${ }^{3}$. About 7 million neonates are born each year in Nigeria of whom 240,000 die during the neonatal period, 94,000 dying on the first day of life ${ }^{4}$. According to the Nigerian Demographic Health Survey, the national NMR was 39/1000 live births ${ }^{5}$, a rate higher than African countries like Ghana and Uganda ${ }^{6}$.

While Nigeria has reduced under-five deaths, it failed to achieve Millennium Development Goal-4 for child survival chiefly because of inadequate decrease in neonatal deaths ${ }^{7}$. The south-south and south-east geopolitical zones of Nigeria have the lowest NMR with 27/1000 live births; the northcentral zone has a rate of $37 / 1000$ live births and the north-west has the highest rate with $46 / 1000$ live births ${ }^{5}$. Chief causes of neonatal deaths are complications of preterm births, perinatal asphyxia and neonatal sepsis ${ }^{5,9,10}$. If Nigeria is to attain the Sustainable Development Goal (SDG) for child survival in 2030, limited resources must be targeted at the determinants of neonatal mortality at the community level. There are limited data to suggest the contributions of these socio-demographic factors to neonatal mortality in Lafia, NorthCentral Nigeria.

\section{Objectives}

To determine the neonatal morbidity pattern and the risk factors associated with neonatal mortality in the neonatal unit of Dalhatu Araf Specialist Hospital (DASH), Lafia, North-Central Nigeria. 


\section{Method}

The study was conducted in the neonatal unit of DASH, a tertiary health facility in Lafia, NorthCentral Nigeria serving as a referral centre for Nasarawa state, and parts of the surrounding states of Benue, Plateau and Kaduna. The unit is equipped and designed to care for the special needs of sick neonates, having 18 cots, oxygen supplies, a radiant warmer, 3 incubators, four phototherapy units and other resuscitation devices. Unit staff includes paediatric nurses, 2 junior resident doctors, a senior registrar and a consultant paediatrician as the head of the unit.

The study is a review of the admission records of neonates to the neonatal unit from $1^{\text {st }}$ January to $31^{\text {st }}$ December 2018. All admissions to the unit during the period under review, were identified by hospital numbers on the admission register. Relevant data, collected from the case files, included gender, age, weight on admission, place of birth, mode of birth, socioeconomic class ${ }^{11}$, diagnosis, parity, maternal age and treatment outcome in terms of death or discharge.

Ethical issues: Ethical clearance was obtained from the Research and Ethics Committee of Dalhatu Araf Specialist Hospital (DASH), Lafia, North-Central Nigeria (No, DASH/L/ADM/017). As the study was a review of the admission records to the neonatal unit during 2018 no informed consent could be obtained.

Statistical analysis: Data were entered into Microsoft Excel spreadsheet and data analysed by SPSS version 23. Frequencies and percentages were used for categorical variables while means and standard deviations were used for continuous variables. The direct causes of deaths were documented and their prevalence determined. Associations between independent variables (possible risk factors) and the dependent variable (death) were determined using Chi square test and logistic regression. Level of significance was set at $p<0.05$.

\section{Results}

Of the 706 admissions to the neonatal unit during the study period, $428(61 \%)$ were reviewed, the data for the remaining neonates being incomplete. Two hundred and seventeen $(50.7 \%)$ were males, $348(81.3 \%)$ were term infants and $373(87.1 \%)$ were delivered in health facilities as shown in Table 1.

The mean age of mothers of the neonates was $27.2 \pm 5.6$ years, the mean parity was $3.2 \pm 2.2$ and the mean gestational age of the neonates was $38.8 \pm 2.7$ weeks as shown in Table 2 .

Three hundred and ninety-two (91.6\%) neonates were admitted in the first week of life and $8.4 \%$ from $2^{\text {nd }}-4^{\text {th }}$ week of life as shown in Table 3 .

Table I: Gender, maturity, place of delivery and mode of delivery of neonates

\begin{tabular}{|l|c|}
\hline Variable & Frequency (\%) \\
\hline Gender & $217(50.7)$ \\
Male & $211(49.3)$ \\
Female & $80(18.7)$ \\
\hline Maturity & $348(81.3)$ \\
Preterm & \\
Term & $373(87.1)$ \\
\hline Place of delivery & $055(12.9)$ \\
Health facility & \\
Home & $256(59.2)$ \\
\hline Mode of delivery & $172(40.8)$ \\
Spontaneous vaginal delivery & \\
Caesarean section &
\end{tabular}

Table 2: Minimum, maximum, mean and standard deviation of neonatal age, weight, maternal age, parity and gestational age at delivery

\begin{tabular}{|l|c|c|c|}
\hline \multicolumn{1}{|c|}{ Variable } & Minimum & Maximum & Mean (SD) \\
\hline Age (hours) & 0.16 & 1056.00 & $59.6(107.6)$ \\
\hline Weight (kg) & 0.80 & 40.00 & $02.8(02.5)$ \\
\hline Maternal age (years) & 16.00 & 46.00 & $27.2(05.6)$ \\
\hline Parity & 01.00 & 12.00 & $03.2(02.2)$ \\
\hline Gestational age (weeks) & 27.00 & 42.00 & $38.8(02.7)$ \\
\hline
\end{tabular}

Table 3: Day of admission of neonates

\begin{tabular}{|l|c|}
\hline Day of life & Frequency (\%) \\
\hline First 24 hours & $242(56.5)$ \\
\hline 2-7 days & $150(35.1)$ \\
\hline 8-28 days & $36(08.4)$ \\
\hline
\end{tabular}

There were $197(46 \%)$ cases of neonatal sepsis (NNS), 96 (22.4\%) cases of perinatal asphyxia and
$45(10.5 \%)$ cases of respiratory distress syndrome (RDS), as shown in Figure 1.

The diagnosis of neonatal sepsis was made on clinical grounds with blood culture proven bacterial sepsis in $118(60 \%)$ cases. Diagnosis of perinatal asphyxia was made on account of persistently low Apgar score of $\leq 3$ in $>5$ minutes after birth, and the presence of at least one of the following; 
abnormal tone, convulsions or altered level of consciousness. The diagnosis of RDS was made in a setting of worsening respiratory distress within the first 24 hours of life in a preterm neonate that is less than 34 weeks gestation at birth.
Neonatal mortality was significantly associated with lower socioeconomic class $(\mathrm{p}=0.03)$, admission within the first 24 hours $(p=0.01))$, low birth weight $(\mathrm{p}=0.001)$ and prematurity $(\mathrm{p}=$ 0.002 ) as shown in Table 4. Low birth weight was defined as a birth weight less than $2.5 \mathrm{~kg}$.

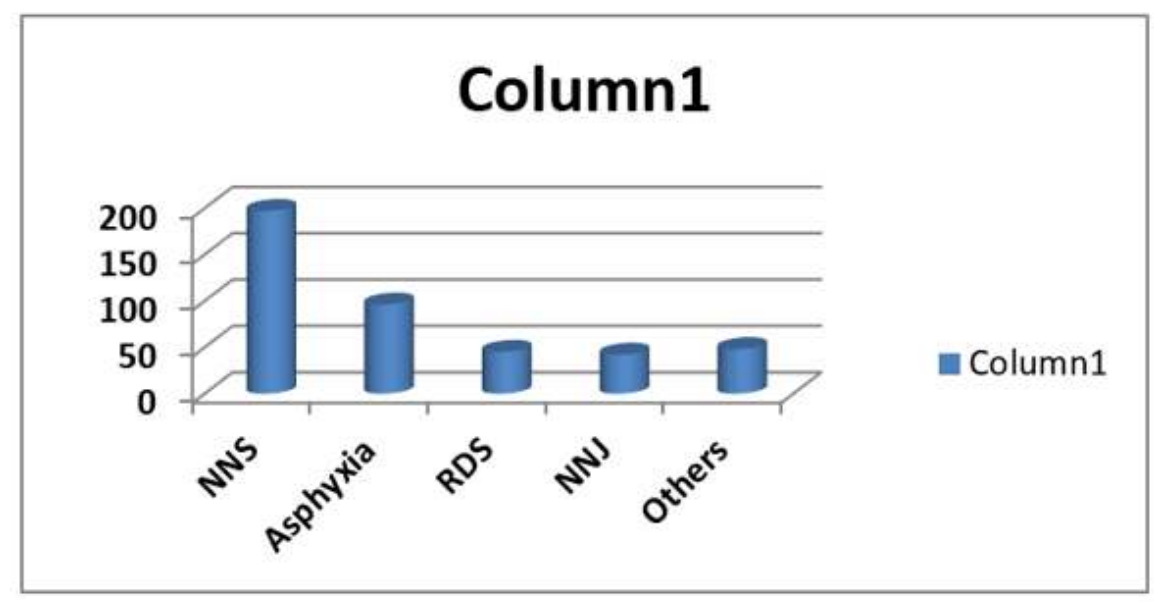

Figure 1: Morbidity pattern of neonates

Table 4: Association between some variables and survival outcome

\begin{tabular}{|c|c|c|c|c|c|}
\hline Variable & $\begin{array}{l}\text { Alive } \\
\text { n (\%) }\end{array}$ & $\begin{array}{l}\text { Died } \\
\text { n (\%) }\end{array}$ & Df & $\mathbf{X}^{2}$ & p-value \\
\hline $\begin{array}{l}\text { Socio-economic class } \\
\text { Upper } \\
\text { Middle } \\
\text { Lower }\end{array}$ & $\begin{array}{c}25(96.2) \\
99(95.2) \\
258(86.9)\end{array}$ & $\begin{array}{l}01(03.8) \\
05(04.8) \\
39(13.1)\end{array}$ & 2 & 6.80 & 0.030 \\
\hline $\begin{array}{l}\text { Date of admission } \\
\text { Day } 1 \\
\text { Days } 2-7 \\
\text { Days } 8-28\end{array}$ & $\begin{array}{l}208(86.0) \\
137(92.6) \\
38(100.0) \\
\end{array}$ & $\begin{array}{c}34(14.0) \\
11(07.4) \\
0(0.0)\end{array}$ & 2 & 8.90 & 0.010 \\
\hline $\begin{array}{l}\text { Gender } \\
\text { Male } \\
\text { Female }\end{array}$ & $\begin{array}{l}193(89.4) \\
189(89.6)\end{array}$ & $\begin{array}{l}23(10.6) \\
22(10.4)\end{array}$ & 1 & 0.01 & 1.000 \\
\hline $\begin{array}{l}\text { Place of delivery } \\
\text { Hospital } \\
\text { Home }\end{array}$ & $\begin{array}{c}335(90.1) \\
47(85.5)\end{array}$ & $\begin{array}{l}37(09.9) \\
08(14.5)\end{array}$ & 1 & 1.05 & 0.300 \\
\hline $\begin{array}{l}\text { Maturity } \\
\text { Term } \\
\text { Preterm }\end{array}$ & $\begin{array}{c}318(91.6) \\
64(80.0)\end{array}$ & $\begin{array}{l}29(08.4) \\
16(20.0)\end{array}$ & 1 & 9.40 & 0.002 \\
\hline $\begin{array}{l}\text { Birth weight } \\
\text { Low } \\
\text { Normal }\end{array}$ & $\begin{array}{l}115(82.1) \\
264(92.9)\end{array}$ & $\begin{array}{l}25(17.9) \\
20(07.1)\end{array}$ & 1 & 11.56 & 0.001 \\
\hline
\end{tabular}

Use of antenatal corticosteroid was found to be strongly associated with increased chance of survival of preterm neonates as shown in Table 5. Antenatal corticosteroids were administered to pregnant women who presented with preterm labour with imminent risk of preterm delivery before 34 weeks gestation. The dose administered was $12 \mathrm{mg} 12$ hourly for 24 hours given via the intramuscular route;

Table 5: Association between survival outcome of preterm neonates and use of antenatal corticosteroid

\begin{tabular}{|l|c|c|c|c|c|c|c|c|}
\hline Variable & Mean GA (SD) & Mean BW (SD) & Discharged & Died & Total & df & $\boldsymbol{X}^{\mathbf{2}}$ & $\boldsymbol{p}$ \\
\hline ACS & $31.1(2.6)$ & $1.3(0.26)$ & $13(92.9)$ & $01(07.1)$ & $14(31.1)$ & 1 & 17.4 & 0.000 \\
\hline No ACS & $31.7(2.6)$ & $1.4(0.35)$ & $08(25.8)$ & $23(74.2)$ & $31(68.9)$ & & & \\
\hline
\end{tabular}

ACS- Antenatal corticosteroid; GA- Gestational age; SD-Standard deviation; $B W$ - Birth weight 
On logistic regression, prematurity was found to be the strongest predictor of mortality $(\mathrm{AOR}=3.7$; $\mathrm{CI}$
$95 \%=1.013 .1 ; p$ value $=0.04)$ as shown in table 6.

Table 6: Logistic regression - Assessing the predictors of mortality from the study

\begin{tabular}{|ll|c|c|c|c|c|c|c|c|}
\hline & & & & & & & \multicolumn{2}{|c|}{$\mathbf{9 5 \%}$ C.I. for EXP(B) } \\
\hline Step 1 $^{\text {a }}$ & Gender (1) & S.E. & Wald & Df & Sig. & Exp (B) & Lower & Upper \\
POD (1) & 0.002 & 0.334 & 0.000 & 1 & 0.995 & 1.002 & 0.521 & 1.927 \\
MOD (1) & 0.814 & 0.590 & 1.905 & 1 & 0.168 & 2.256 & 0.710 & 7.164 \\
Parity & 0.090 & 0.357 & 0.064 & 1 & 0.801 & 1.094 & 0.543 & 2.206 \\
Booking (1) & 0.037 & 0.073 & 0.250 & 1 & 0.617 & 1.037 & 0.898 & 1.198 \\
SEC & -0.026 & 0.802 & 0.001 & 1 & 0.974 & 0.975 & 0.202 & 4.697 \\
SEC (1) & & & 1.361 & 2 & 0.506 & & & \\
SEC (2) & -0.287 & 0.783 & 0.135 & 1 & 0.714 & 0.750 & 0.162 & 3.482 \\
Weight class & -0.496 & 0.432 & 1.318 & 1 & 0.251 & 0.609 & 0.261 & 1.421 \\
GA (preterm/term) & -0.434 & 0.428 & 1.028 & 1 & 0.311 & 0.648 & 0.280 & 1.499 \\
Age class & 1.302 & 0.647 & 4.048 & 1 & 0.044 & 3.675 & 1.034 & 13.061 \\
Constant & -0.063 & 0.274 & 0.053 & 1 & 0.818 & 0.939 & 0.549 & 1.606 \\
\hline
\end{tabular}

POD-Place of delivery; MOD-Mode of delivery; SEC-Socio-economic class; GA-Gestational age

Of the 428 cases reviewed, there were 45 (10.5\%) deaths. Sixteen (37\%) deaths were due to asphyxia, $14(33 \%)$ due to RDS and $13(30 \%)$ due to NNS as shown in Figure 2. However, RDS had the highest case fatality rate $(31.1 \%)$, followed by asphyxia (16.7\%) and NNS (6.6\%).

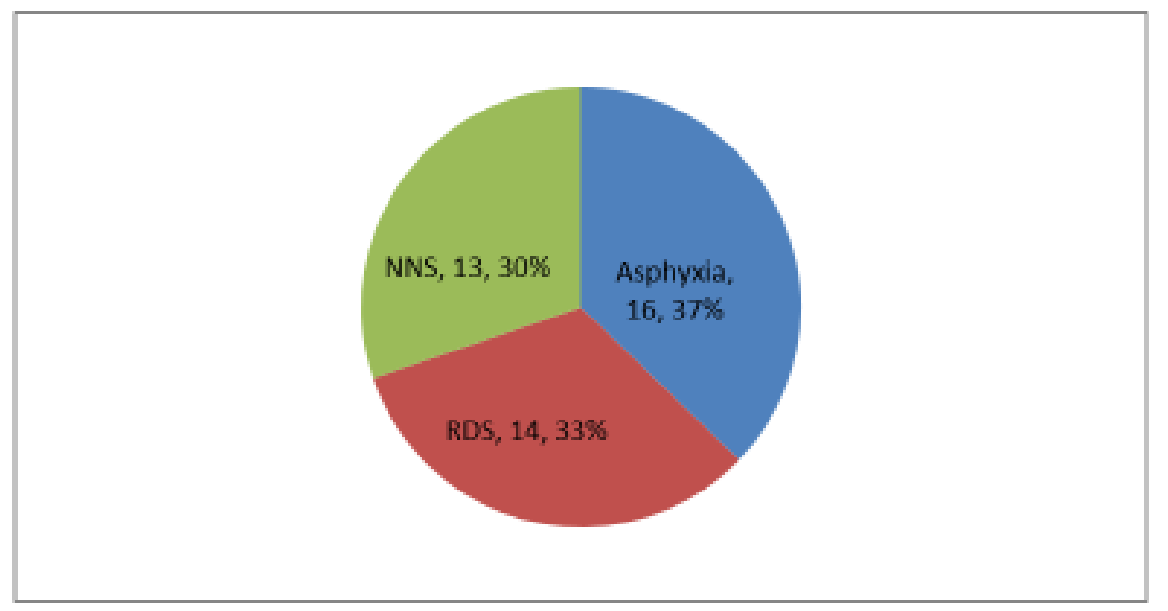

Figure 2: Clinical diagnoses and proportion of mortality

\section{Discussion}

The proportion of neonatal deaths recorded in the present study (10.5\%), was lower than that reported in Enugu in Eastern Nigeria and Ibadan in Western Nigeria $^{12,13}$. It was also lower than the $20 \%$ reported in neonatal units of Ethiopian hospitals and the $20.2 \%$ recorded in Eastern Nepal ${ }^{14,15}$. A possible explanation for the lower NMR in the current study compared to other reports could be the referral of severe congenital anomalies and neonatal surgical emergencies to other health facilities due to lack of specialist care to manage them at the study centre.

The causes of neonatal deaths in the present study were RDS, birth asphyxia and NNS. Several studies have reported these 3 clinical diagnoses as the most important causes of deaths among neonates ${ }^{12,13,16}$. In the past, NNS was the leading cause of neonatal deaths accounting for $30-50 \%$ of them ${ }^{17,18}$. However, recent studies ${ }^{16,19,20}$ have shown that prematurity is now the leading cause of neonatal mortality globally and this is reflected in the present series. This is probably due to the introduction of chlorhexidine as the standard cord care to prevent NNS. Chlorhexidine cord care was first introduced in Nigeria in 2012 as a strategy to reduce neonatal mortality from $\mathrm{NNS}^{21}$.

RDS, which is due to immaturity of the lungs of a preterm neonate delivered before 34 completed weeks, remains a major challenge in Nigeria for many reasons. World Health Organization (WHO) guidelines on management of premature labour recommends using antenatal steroids to hasten lung maturation in labour occurring before 34 completed 
weeks ${ }^{22}$. However, in Nigeria, a significant proportion of pregnant women do not attend antenatal care, and out-of-hospital delivery is common $^{5,23}$. This presents a huge challenge for high risk pregnancies such as preterm labour as the opportunity to administer corticosteroid is often missed.

In the present series, more than $70 \%$ of neonates that died from RDS were delivered to mothers who presented late to delivery centres, and as a result were not given antenatal corticosteroids to hasten the lung maturation of their neonates. Antenatal corticosteroids significantly reduced the risk of neonatal mortality in the present series and this has been widely reported in the literature ${ }^{24,25}$. Surfactant administration to premature neonates is not a common practice in most Nigerian hospitals because very few parents can afford it and the expertise for its administration is not widely available $^{26}$. The only treatment modality for neonates with RDS at the study centre was improvised Bubble CPAP ventilation. The results from the present study revealed that preterm neonates whose mothers were not given antenatal corticosteroid were more likely to die than neonates whose mothers received antenatal corticosteroid.

Asphyxia is an equally important cause of death in most developing countries because of the low patronage of antenatal services and the high level of unskilled deliveries in Nigeria ${ }^{5,23}$. Even where mothers present to health facilities to have their neonates delivered, many health facilities are ill prepared to resuscitate a severely asphyxiated neonate. Asphyxia in a developing country like Nigeria is better prevented than managed as the outcome of neonates who survive is usually poor ${ }^{27}$, If the burden of asphyxiated neonates is to be reduced, focused antenatal care coverage must be scaled up, skilled delivery must be made universally available to Nigerian women and neonatal resuscitation training must be routine in delivery units in our hospitals.

About $75 \%$ of neonatal deaths were recorded during the first 24 hours of life in the present study, and a similar finding has been reported by other authors ${ }^{12,16,19}$. The first 24 hours of life is the time newborns undergo physiologic and anatomic cardiopulmonary changes as they transit from an intrauterine circulation to an extra-uterine circulation. Since the first 24 hours is so critical to the survival of a newborn, it is common sense to evaluate and closely monitor every newborn for at least 24 hours after delivery in order to detect any health problems and intervene early. WHO recommendation for postnatal care states that mothers and newborns should receive postnatal care in health facilities for at least 24 hours after normal delivery. It also states that three additional postnatal care visits should be made on day 3 , on any day from 7-14 and at 6 weeks of life ${ }^{29}$. During postnatal care, neonates should be assessed for signs of neonatal diseases, and when present, immediate referral for further evaluation and management should be effected.

Unfortunately, due to lack of bed spaces in most health facilities in Nigeria, apparently normal deliveries are usually discharged 4-6 hours after birth so as to create bed spaces for other patients. Postnatal care in Nigeria is provided only at 6 weeks after delivery for those mothers who care enough to return back to the health facility. Since most neonatal deaths occur in the first week of life, and about two-third of infant mortality occur in the first month of life $\mathrm{e}^{30,31}$, these visits recommended by WHO would have been golden opportunities to prevent these deaths. If neonatal deaths are to be appreciably reduced and the SDG for child survival attained, then health managers must make provisions for bed spaces and manpower to cater for women and their newborns for at least 24 hours after delivery, and ensure subsequent postnatal care either as home visits or as hospital visits.

Neonatal mortality was strongly associated with low social class, preterm delivery and low birth weight. However, on logistic regression, prematurity increased the likelihood of death to about 3.7 times; thus prematurity is the most important predictor of neonatal death. In a study in Wesley Guild Hospital, Ilesha, Nigeria, prematurity, low birth weight and low social class were reported as the major determinants of neonatal deaths ${ }^{32}$. Though in the study carried out in Ilesha, teenage pregnancy was also found to be a determinant of neonatal death, in the present study, teenage pregnancy was not associated with neonatal death. In a study by Debelew GT, et al carried out in North Gondar Zone in Northwest Ethiopia, low birth weight, lack of formal education in mothers (a reflection of low social class), neonatal illnesses, and maternal illnesses were found to be associated with neonatal death ${ }^{33}$. The present study did not consider maternal illness as a risk factor for neonatal mortality and other studies also have not found maternal illnesses to be a risk factor for neonatal mortality ${ }^{34,35}$.

\section{Conclusions}

The three leading causes of neonatal morbidity and mortality at the study centre were RDS, perinatal asphyxia and neonatal sepsis. However, prematurity was the most important predictor of mortality. 


\section{References}

1. Pritchett L, Summers LH. Wealthier is healthier. Journal of Human Resources 1996; 31:841-68.

https://doi.org/10.2307/146149

2. Bhalotra S. Childhood mortality and economic growth. The Centre for Market and Public Organization (CMPO) Working Paper Series No. 08/188. 2006. University of Bristol, Bristol, UK.

3. WHO. Newborns: reducing mortality. 2019. Available from: www.who.int/newsroom/factsheets/detail/ newborns-reducing-mortality (Accessed on $08 / 10 / 2019$ )

4. UNICEF. New Year's babies: more than 25000 babies will be born in Nigeria on New Year's Day. UNICEF Press release. 2019. Available from:

www.unicef.org/nigeria/pressreleases/new -years-babies-more-25000-babies-will-beborn-nigeria-news (Accessed on 08/10/2019)

5. National Population Commission (NPC) [Nigeria] and ICF. 2019. Nigeria Demographic and Health Survey 2018. Abuja, Nigeria, and Rockville, Maryland, USA: NPC and ICF.

6. Office of the Senior Special Assistant to the President on Millennium Development Goals (OSSAP-MDG). Nigeria 2015 Millennium Development Goals EndPoint Report [internet]. Abuja-Nigeria: OSSAP-MDG; 2015. 28 p. Available from: www.mdgs.gov.ng (Accessed on 08/10/2019)

7. Lawn JE, Kerber K, Enweronu-Laryea C, Cousens S. 3.6 million neonatal deaths: What is progressing and what is not. Seminars in Perinatology 2010; 34: 37186.

https://doi.org/10.1053/j.semperi.2010.09. 011

PMid: 21094412

8. Partnership for maternal, newborn and child health. Child mortality: millennium development goal 4.2011. Available from: www.who.int/pmnch/media/press_materia ls/fs/fs_mdg4_childmortality/en/ (Accessed on 08/10/2019)
9. Adimora GN, Odetunde IO. Perinatal mortality in University of Nigeria Teaching Hospital (UNTH) Enugu at the end of the last millennium. Nigerian Journal of Clinical Practice 2007; 10: 1923. https://doi.org/10.4314/wajr.v10i1.34197

10. Udo JJ, Anah MU, Ochigbo SO, Etuk IS, Ekanem AD. Neonatal morbidity and mortality in Calabar, Nigeria: a hospitalbased study. Nigerian Journal of Clinical Practice 2008; 11: 285-9.

11. Oyedeji GA. Socio-economic and cultural background of hospitalized children in Ilesa. Nigerian Journal of Paediatrics 1985; 12: 111-7.

12. Ekwochi U, Ndu IK, Nwokoye IC, Ezenwosu OU, Amadi OF, Osuorah DIC. Pattern of morbidity and mortality of newborns admitted into the sick and special care baby unit of Enugu state university teaching hospital, Enugu state. Nigerian Journal of Clinical Practice 2014; 17: 346-51.

https://doi.org/10.4103/1119-3077.130238 PMid: 24714015

13. Elizabeth IU, Oyetunde MO. Pattern of diseases and care outcomes of neonates admitted in special care baby unit of University College Hospital, Ibadan, Nigeria from 2007 to 2011. IOSR Journal of Nursing and Health Science 2015; 4(3): 62-71.

14. Tekleab AM. Amaru GM and Tefera YA. Reasons for admission and neonatal outcome in the neonatal care unit of a tertiary care hospital in Addis Ababa: a prospective study. Research and Reports in Neonatology 2016; 6(2016): 17-23. https://doi.org/10.2147/RRN.S95455

15. Shah GS, Yadav S, Thapa ASL. Clinical profile and outcome of neonates admitted to neonatal intensive care unit (NICU) at a tertiary Care Centre in Eastern Nepal. Journal of Nepal Paediatric Society 2013; 4(3):1511-6.

https://doi.org/10.3126/jnps.v33i3.8447

16. Toma BO, Ige OO, Abok II, Onwuanaku C, Abah RO, Donli A. Pattern of neonatal admissions and outcome in a tertiary 
institution in north central Nigeria. Journal of Medicine in the Tropics 2013; 15: 121-5.

https://doi.org/10.4103/2276-7096.123590

17. Bang AT, Bang RA, Baitule SB, Reddy $\mathrm{MH}$, Deshmukh MD. Effect of homebased neonatal care and management of sepsis on neonatal mortality: field trial in rural India. Lancet 1999; 354(9194): 1955-61.

https://doi.org/10.1016/S01406736(99)030 46-9

18. Stoll BJ. The global impact of neonatal infection. Clinical Perinatology 1997; 24(1): 1-21.

https://doi.org/10.1016/S01406736(99)03

046-9

19. Okechukwu AA, Achonwa A. Morbidity and mortality patterns of admissions into the Special Care Baby Unit of the University of Abuja Teaching Hospital, Gwagwalada, Nigeria. Nigerian Journal of Clinical Practice 2009; 12(4): 389-94.

20. Walana W, Acquah EK, Abdul-Mumin A, Naafu B, Aruke E, Vicar KE. Pattern, causes and treatment outcomes of neonatal admissions in the Tamale Teaching Hospital. Clinics in Mother and Child Health 2016; 13(4): https://doi.org/10.4172/20907214.100025 2

21. Scaling up chlorhexidine for umbilical cord care in Nigeria: A commitment to reducing newborn deaths from sepsis.

Available from:

https:/www.healthynewbornnetwork.org/ hnn-content/uploads/Nigeria-CHX-ScaleBrief.pdf (Accessed 12/06/2019).

22. World Health Organization. WHO recommendation on antenatal corticosteroid therapy for women at risk of preterm birth from 24 weeks to 34 weeks of gestation. 2015. Available from:

https:/extranet.who.int/rhl/topics/preconc eption-pregnancy-childbirth-and postpartum-care/pregnancycomplications/preterm-birth/whorecommendation-antenatal-corticosteroidtherapy-women-risk-preterm-birth-24-

weeks-34-weeks (Accessed on 08/10/2019).
23. Nghargbu R, Olaniyan O. Determinants of antenatal care utilization in Nigeria. Working paper series, No. 321. African Development Bank Group. July 2019. Available from:

https://www.afdb.org/sites/default/files/do cuments/publications/wps_no. 321_deter minant_of_antenatal_care_utilization_in nigeria_final_correction.pdf (Accessed on 08/10/2019).

24. Liggins GC, Howie RN. A controlled trial of antepartum glucocorticoid treatment for prevention of the respiratory distress syndrome in premature infants. Pediatrics 1972; 50(4): 515-25.

25. Crowley P, Chalmers I, Keirse MJ. The effects of corticosteroid administration before preterm delivery: an overview of the evidence from controlled trials. British Journal of Obstetrics and Gynaecology 1990; 97(1): 11-25. https://doi.org/10.1111/j.14710528.1990.t b01711.x

PMid: 2137711

26. Okonkwo IR, Okolo AA. The scope and extent of exogenous surfactant utilization in Nigeria health care facilities: benefits of its regular use to outcome of premature babies. Journal of Maternal-Fetal and Neonatal Medicine 2020; 33: 1276-81.

27. Uleanya ND, Aniwada EC, Ekwochi U, Uleanya ND. Short term outcome and predictors of survival among birth asphyxiated babies at a tertiary academic hospital in Enugu, South East, Nigeria. African Health Sciences 2019; 19(1): 1554-62.

https://doi.org/10.4314/ahs.v19i1.29 PMid: 31148983 PMCid: PMC6531974

28. Idris U. Perinatal asphyxia in term neonates seen in Federal Medical Centre, Birnin Kudu, Nigeria. IJHAS 2019; 8: 118. https://doi.org/10.4103/ijhas.IJHAS_11_1 8

29. World Health Organization. WHO Technical Consultation on Postpartum and Postnatal Care. 2010. WHO Press. Geneva, Switzerland.

30. World Health Organization. Newborns: reducing mortality. 2018. Available from: www.who.int/news-room/fact- 
sheet/details/newborns-reducing-mortality (Accessed on 27/06/2019)

31. Rutstein SO. Factors associated with trends in infant and child mortality in developing countries during the 1990s. Bulletin of the WHO 2000; 78(10):125670.

32. Onayade AA, Sule SS, Elusiyan JB. Determinants of neonatal mortality at Wesley Guild Hospital, Ilesa, Nigeria. Nigerian Journal of Medicine 2006; 15(3): 271-6.

https://doi.org/10.4314/njm.v15i3.37227

PMid: 17111757

33. Debelew GT, Afework MF, Yalew AW. Determinants and causes of neonatal mortality in Jimma Zone, Southwest Ethiopia: a multilevel analysis of prospective follow up study. PLoS One 2014; 9(9): e107184.

https://doi.org/10.1371/journal.pone.0107

184

PMid: 25232842 PMCid: PMC4169420
34. De Souza S, Duim E, Nampo F.K. Determinants of neonatal mortality in the largest international border of Brazil: a case-control study. BMC Public Health 2019. 19: 1304 https://doi.org/10.1186/s12889-019-76388

PMid: 31619198 PMCid: PMC6796356

35. Kolola T, Ekubay M, Tesfa E, Morka W. Determinants of neonatal mortality in north Shoa Zone, Amhara regional state, Ethiopia. PLoS One. 2016; 11(10): https://doi.org/10.1371/journal.pone.0164 472

PMid: 27741284 PMCid: PMC5065191 